\title{
Observations on the lungs of vanadium workers
}

\author{
M KIVILUOTO
}

From the Health Center of the Otanmäki Mine of Rautaruukki Company, SF-88200 Otanmäki, Finland

ABSTRACT Out of a total of 79 employees at a factory making vanadium pentoxide from magnetite ore 63 were investigated by respiratory questionnaire, chest radiography, and tests of ventilatory function. The findings were compared with a reference group of 63 men, matched for age (to within two years) and for smoking habit (to within five cigarettes daily) selected from workers at a magnetite ore mine. Analysis of the ventilation tests showed no significant differences between the reference group and the men exposed to low concentrations of vanadium $\left(0.01-0.04 \mathrm{mg} / \mathrm{m}^{3}\right)$, despite previous exposure for an average of 11 years to concentrations in the range of 0.1 to $3.9 \mathrm{mg} / \mathrm{m}^{3}$. Complaint of wheezing vas significantly more common among the workers exposed to vanadium than among their referents, but there were no other subjective differences between the groups. Localised fibrotic foci were reported in the radiographs of four reference cases and two men exposed to vanadium, but there were no cases of pneumoconiosis in either group.

The world production of vanadium was about 35000 tons in 1975. The largest producers were South Africa, the United States, the Soviet Union, Finland, Namibia, Norway, and Chile. Vanadium is commonly separated from carnotite and titanomagnetite ores. It is used in the steel industry as an alloy substance to improve the properties of steel, as well as in the chemical industry as a catalyst. Exposure to vanadium is possible during the different stages of its separation, in the steel industry, and in certain branches of the chemical industry. It may also occur when oil- or gas-fired boilers are being cleaned or repaired ${ }^{12}$ as some oils contain vanadium.

Vanadium enters the body mainly through the lungs, and is excreted in the urine and also, to a minor degree, in the faeces. ${ }^{3} 4$ The metabolic effects of vanadium are probably due to its oxidising capacity. 5 The symptoms of vanadium poisoning ${ }^{136-15}$ are: irritation of the upper respiratory tract, nasal catarrh and haemorrhage, stinging pain in the throat, cough, and wheezing. Chronic rhinitis, bronchitis, and conjunctivitis have been reported after prolonged exposure. Exposure to vanadium may also result in pneumonia, ${ }^{810}$ but permanent damage to the lungs or carcinogenic effects have not been reported.10

The present investigation was undertaken in the vanadium factory of the Otanmäki Mine of Rautaruukki Company, Finland, which has been

Received 2 May 1979

Accepted 27 July 1979 manufacturing vanadium pentoxide since 1956 . The annual output is up to 2400 tons. In the process magnetite is roasted with sodium carbonate. The roasted product is leached, and vanadates are precipitated from the leach liquor. The "red cake" produced is filtered, washed, and smelted to vanadium pentoxide. Control of vanadium dust has been difficult at the smelting furnaces and during the packing of pentoxide smelt, processing the filtered precipitate, and grinding the laboratory samples.

Table 1 shows the concentrations of vanadium dust in the factory before this study. They have been determined from the total amount of dust collected during 1-3 hours. In the dustiest areas the concentration of vanadium in the air exceeded or equalled the threshold limit value (TLV) recommended by the American Conference of Governmental Industrial Hygienists. ${ }^{16}$

This case-control study examines the possible effects of vanadium exposure on ventilatory function, findings in chest radiographs, and respiratory symptoms in the workers of the vanadium factory.

\section{Population and methods}

The exposed population consisted of 63 men, who were process workers, repairmen, foremen, and laboratory workers in the vanadium factory. Every man who had worked in the vanadium factory for at least four months was selected for examination, but those on holiday or sick leave at that time were not seen. The reference group of 63 men was chosen 
Table 1 Previous total vanadium concentrations in the air $\left(\mathrm{mg} / \mathrm{m}^{3}\right)$

\begin{tabular}{|c|c|c|c|c|c|c|c|c|}
\hline \multirow[t]{2}{*}{ Site or job } & \multicolumn{8}{|c|}{ Time of measurement } \\
\hline & $\begin{array}{l}\text { Jan } \\
57\end{array}$ & $\begin{array}{l}\text { Mar } \\
70\end{array}$ & $\begin{array}{l}\text { Feb } \\
72\end{array}$ & $\begin{array}{l}\text { Apr } \\
72\end{array}$ & $\begin{array}{l}\text { May } \\
72\end{array}$ & $\begin{array}{l}\text { Oct } \\
73\end{array}$ & $\begin{array}{l}\text { Mar } \\
74\end{array}$ & $\begin{array}{l}\text { May } \\
75\end{array}$ \\
\hline Sintering furnaces (discharge) & $0 \cdot 1$ & $0 \cdot 1$ & 0.0 & & & & & \\
\hline Packing of smelt & 3.9 & 0.9 & 0.2 & $0 \cdot 2$ & 0.05 & $0 \cdot 1$ & $0 \cdot 1$ & 0.6 \\
\hline Smelt furnaces & & 1.9 & 0.5 & 0.2 & 0.8 & & 1.0 & \\
\hline Packing of precipitate & $0 \cdot 0$ & $0 \cdot 1$ & 0.3 & & & & $0 \cdot 3$ & \\
\hline Grinding of samples & & & & & $1 \cdot 10$ & & & \\
\hline Sintering furnaces (charging) & 0.2 & & & & & & & \\
\hline Filtering & & 0.01 & $0 \cdot 2$ & & & $0 \cdot 2$ & & 0.5 \\
\hline Pelleting machine & $0 \cdot 1$ & $0 \cdot 1$ & & & & 0.0 & & \\
\hline
\end{tabular}

from men living in the same area and thus exposed to similar air pollution. The referents worked in the concentrating plant, the mine, the repair shop, and the office, and they were matched for age within two years and for the number of cigarettes smoked daily within five cigarettes. All the subjects consented to the examination.

Forced vital capacity (FVC) and forced expiratory volume $\left(F E V_{1}\right)$ were determined with a dry bellows spirometer (Vitalograph) and expressed at BTPS. The highest value out of five attempts was used. Investigation of the exposed men took place at the end of their summer holidays in 1975, and at the same time the assisting nurse filled in a standardised questionnaire on respiratory symptoms. ${ }^{17}$ Lung function tests of the reference group were also undertaken in summer 1975. Full-size chest radiographs were taken in April 1976 and read, mixed and "blind," by an experienced radiologist at the Institute of Occupational Health of Finland.

The concentrations of vanadium dust at various sites in the factory were determined on eight days in March-May 1976. The determination covered two whole shifts. An atomic absorption spectrophotometer using the flameless graphite atomiser (PerkinElmer 300, HGA 74) was used for these determinations. This could detect vanadium down to $0.002 \mathrm{mg} / \mathrm{m}^{3}$. The coefficient of variation within-run was $6 \%$ at the concentration level of $0.05 \mathrm{mg} / \mathrm{m}^{3}$. The particle size of the dust samples was determined by a modified Andreasen method from five dust samples, which were taken separately with a high volume sampler. ${ }^{18}$

Because the exposed and reference populations were matched for age and smoking habit, the use of Cole's ${ }^{19}$ finding that $\mathrm{FEV}_{1}=$ height $^{2} \times(c+d \times$ age $)$ simplified the analysis to a paired $t$-test of the differences

$$
\frac{\text { FEV }}{\text { Height }^{2}} \text { (exposed) }-\frac{\text { FEV }_{1}}{\text { Height }^{2}} \text { (referent) }
$$

The distribution of repiratory symptoms between the exposed and referents was analysed by McNemar's test for paired observations.

\section{Results}

COMPARABILITY OF THE EXPOSED AND THE REFERENCE GROUP

The average smoking time of the smokers within the exposed group was 15.8 years and that of the smokers within the reference group 16.0 years. The average amounts in grams of tobacco smoked were $14 \mathrm{~g}$ and $12.5 \mathrm{~g}$ a day respectively.

In the age group 19-39 the average height of the exposed group was $170.8 \mathrm{~cm}$ and the height of the referents 175.6; in the age group 40-56 the average heights were $170.0 \mathrm{~cm}$ and $171.7 \mathrm{~cm}$, respectively. For the whole sample, the height of there ferents was significantly greater $(p<0.01)$ (table 2$)$, but there was no difference in the weights of the two groups (table 3).

Table 2 Height of the subjects $(\mathrm{cm})$

\begin{tabular}{lcc}
\hline & Exposed group & Reference group \\
\hline Mean & $170 \cdot 4^{*}$ & $173 \cdot 8^{*}$ \\
Standard deviation & $5 \cdot 9$ & $6 \cdot 1$ \\
No of subjects & 63 & 63 \\
\hline
\end{tabular}

$* \mathrm{p}<0.01$.

Table 3 Weight of the subjects $(\mathrm{kg})$

\begin{tabular}{lll}
\hline & Exposed group & Reference group \\
\hline Mean & $76 \cdot 9^{*}$ & $77 \cdot 5^{*}$ \\
Standard deviation & $10 \cdot 1$ & $10 \cdot 0$ \\
No of subjects & 63 & 63 \\
\hline
\end{tabular}

$* p>0.1$.

\section{DUST CONCENTRATIONS}

The concentration of vanadium in the air (table 4) was lower at the time of this survey than in the previous analyses (table 1). The respirable fraction of the 
Table 4 Total vanadium concentrations in the air $\left(\mathrm{mg} / \mathrm{m}^{3}\right)$

\begin{tabular}{llcc}
\hline Site or job & $\begin{array}{l}\text { No of workers on } \\
\text { sites }\end{array}$ & No of samples & $\begin{array}{l}\text { Range } \\
\text { concentration }\end{array}$ \\
\hline Breathing zone samples covering whole shift & 58 & 112 & $0 \cdot 028$ \\
Breathing zone samples at grinding (1-h samples) & 1 & 2 & $0 \cdot 002-0 \cdot 42$ \\
Stationary samples covering whole shift & 15 & 80 & $0 \cdot 25-4 \cdot 7$ \\
Packing of smelt (1-h samples) & 1 & 7 & $0 \cdot 002-0 \cdot 043$ \\
Grinding room & 1 & 1 & $0 \cdot 020-0 \cdot 37$ \\
\hline
\end{tabular}

dust (particle size $5 \mu \mathrm{m}$ or less) was $20 \%$. Concentrations exceeding the TLV of $0.5 \mathrm{mg} / \mathrm{m}^{3}$ were found only during the grinding process of the laboratory samples. High concentrations of vanadium were also found at the packing of the smelt, but elsewhere in the factory the vanadium concentration was constantly below $0 \cdot 1 \mathrm{mg} / \mathrm{m}^{3}$.

\section{VENTILATORY FUNCTION}

There were no significant differences between the ventilatory measurements of the exposed workers and those of their referents $(t=0.09, \mathrm{p}>0.1$ for $\mathrm{FEV}_{1}$ and $t=0.01, \mathrm{p}>0.1$ for $\mathrm{FVC}, \mathrm{DF}=110$ ). Regression analysis showed no significant correlation $(p>0 \cdot 1)$ between $\mathrm{FEV}_{1}$ and duration of exposure to vanadium dust.

\section{CHEST RADIOGRAPHS}

Two men of the exposed group and four men of the reference group had localised fibrotic foci. The remainder had essentially normal chest radiographs.

\section{RESPIRATORY SYMPTOMS}

The exposed men had significantly more wheezing than the referents (table 5). There were no significant differences, however, in the prevalence of nasal catarrh, cough, phlegm, or other respiratory symptoms.

Table 5 Occurrence of wheezing in the exposed and reference groups (63 pairs)*

\begin{tabular}{lll}
\hline Reference group & \multicolumn{2}{l}{ Exposed group } \\
\cline { 2 - 3 } & $\begin{array}{l}\text { Never or } \\
\text { sometimes }\end{array}$ & $\begin{array}{l}\text { On most days or } \\
\text { nights }\end{array}$ \\
\hline Never or sometimes & 30 & 22 \\
On most days or nights & 8 & 3 \\
\hline
\end{tabular}

*Significantly $(\mathrm{p}<0.05)$ more wheezing in the exposed group. $x^{2}=6.5(\mathrm{DF}=1)$.

\section{Discussion}

The present low concentrations of vanadium in the air were probably due to intensified flushing of the factory floors, started in 1976 to stop the dust rising in the air. No association was found between exposure to vanadium dust and alterations of either ventilatory function or chest radiographs in this casecontrol survey.

This investigation suggests that vanadium dust in low concentrations $\left(0.01-0.04 \mathrm{mg} / \mathrm{m}^{3}\right)$, or even in higher concentrations $\left(0 \cdot 2-0.5 \mathrm{mg} / \mathrm{m}^{3}\right)$ endured for years (the average working period was about 11 years under these conditions), does not cause any significant changes in chest radiographs or lungfunction tests. No cases of pneumoconiosis or cancer were found. The only symptom relating to exposure was wheezing, which occurred significantly more often in the workers exposed to vanadium. In view of the results of lurg function tests the clinical significance of this fi ling is uncertain.

I thank Dr E Huhti for his advice, and Ms A Laatikainen, Ms A Tuura, Mr O Juutinen, Mr P Kiviluoto, and Mr J Saukkonen for their skilful help. I am indebted to Rautaruukki Company for the possibility of conducting this study. Without the cooperation of both the workers and the management this work would not have been possible.

\section{References}

${ }^{1}$ Williams $\mathrm{N}$. Vanadium poisoning from cleaning oilfired boilers. Br J Ind Med 1952;9:50-5.

${ }^{2}$ Browne RC. Vanadium poisoning from gas turbines. $\mathrm{Br} J$ Ind Med 1955;12:57-9.

${ }^{3}$ Sjöberg S-G. Vanadium pentoxide dust: a clinical and experimental investigation on its effect after inhalation. Acta Med Scand 1950;(suppl 238), 138:1-188.

+ Dimond EG, Caravaca J, Benchimol A. Vanadium, excretion, toxicity, lipid effect in man. Am J Clin Nutr $1963 ; 12: 49-53$.

${ }^{5}$ Committee on Biologic Effects of Atmospheric Pollutants. Vanadium, medical and biologic effects of environmental pollutants. Washington: National Academy of Sciences, 1974.

${ }^{6}$ Dutton WF. Vanadiumism. JAMA 1911;56:1648.

' Symanski J. Gewerbliche vanadinschädigungen, ihre entstehung und symptomatologie. Archiv für Gewerbepathologie und Gewerbehygienie 1939;9:295-313.

${ }^{8}$ Wyers $\mathrm{H}$. Some toxic effects of vanadium pentoxide. $\mathrm{Br} \mathrm{J}$ Ind Med 1946;3:177-82.

${ }^{9}$ Wyers $H$. Some recent observations on the hazards in the chemical industry. Proceedings 9 th International Congress of Industrial Medicine. Bristol: John Wright, 1948:900.

${ }^{10}$ Sjöberg S-G. Vanadium dust, chronic bronchitis and possible risk of emphysema: a follow-up investigation of 
workers at a vanadium factory. Acta Med Scand 1956; 154:381-6.

11 Frost J. Vanadiumforgiftning ved rensning af oliefyrede kedler. Ugeskr Laeger 1951;113:1309-12.

12 Pielsticker F. Gesundheitsschädigungen durch vanadiumverbindungen. Ihre symptomatologie und prognose. Archiv für Gewerbepathologie und Gewerbehygienie 1954; 13:73-96.

${ }^{13}$ Vintinner FJ, Vallenas R, Carlin CE, Weiss R, Macher C, Ochoa R. Study of the health of workers employed in mining and processing of vanadium ore. Arch Ind Health 1955;12:635-42.

14 Gulko AG. Zur characteristik des vanadiums als industriegift. Gig Sanit 1956;21:24-8.

${ }^{15}$ Mantantseva EJ. Condition of the respiratory organs in workmen handling vanadium pentoxide, Gig $\operatorname{Tr}$ Prof Zabol 1960;7:41-4.

16 American Conference of Governmental Industrial Hygienists. Threshold limit values for chemical substances in workroom air adopted by ACGIH for 1976. Ohio: Cincinnati, 1976.

${ }^{17}$ Medical Research Council, Committee on Research into Chronic Bronchitis. Questionnaire on respiratory symptoms. London: MRC, 1966.

18 Öhman H, Ödelycke P. Provtagnings- och analysförfaranden för silikosfarligt damm (AI-rapport No 3). Stockholm: Arbetsmedicinska Institutet, 1968:20.

${ }^{19}$ Cole TJ. Linear and proportional regression models of ventilatory function. Journal of the Royal Statistical Society, Series A 1975;138:297-337.

\section{Vancouver style}

All manuscripts submitted to the $\mathrm{Br} J$ Ind Med should conform to the uniform requirements for manuscripts submitted to biomedical journals (known as the Vancouver style).

The $\mathrm{Br} J$ Ind Med, together with many other international biomedical journals, has agreed to accept articles prepared in accordance with the Vancouver style. The style (described in full in Br Med J, 24 February 1979, p 532) is intended to standardise requirements for authors.

References should be numbered consecutively in the order in which they are first mentioned in the text by Arabic numerals above the line on each occasion the reference is cited (Manson ${ }^{1}$ confirmed other reports ${ }^{2-5} \ldots$. . In future references to papers submitted to the $\mathrm{Br} J$ Ind Med should include: the names of all authors if there are six or less or, if there are more, the first three followed by et al; the title of journal articles or book chapters; the titles of journals abbreviated according to the style of Index Medicus; and the first and final page numbers of the article or chapter.

Examples of common forms of references are:

1 International Steering Committee of Medical Editors. Uniform requirements for manuscripts submitted to biomedical journals. Br Med J 1979;1 :532-5.

2 Soter NA, Wasserman SI, Austen KF. Cold urticaria: release into the circulation of histamine and eosinophil chemotactic factor of anaphylaxis during cold challenge. $N$ Engl J Med 1976;294:687-90.

${ }^{3}$ Weinstein L, Swartz MN. Pathogenic properties of invading micro-organisms. In: Sodeman WA Jr, Sodeman WA. eds. Pathologic physiology: mechanisms of disease. Philadelphia: W B Saunders, 1974:457-72. 